\title{
Islamic Occultism and the Museum
}

Francesca Leoni, Ashmolean Museum of Art and Archaeology, University of Oxford

\begin{abstract}
The exhibition Power and Protection: Islamic Art and the Supernatural, held at the
\end{abstract} Ashmolean Museum, Oxford, between 20 October 2016 and 15 January 2017, provided the opportunity to reconsider some of the parameters employed in large-scale Islamic art exhibitions. The subject of the show - select divinatory and amuletic practices, itself a break from more conventional themes - was explored by adopting a more inclusive and critical approach, drawing evidence from a wide social spectrum and transcending classifications of 'ethnographic material' and 'fine art'. Attention was also given to daily practice, creating a fresh vantage point to reflect on the role and forms of devotion and broader notions of belief. While presenting practices and evidence that many might deem marginal (and that have certainly been marginalized over time), the exhibition ultimately offered a new analytical lens to challenge hierarchies of higher and lower culture, as well as sanctioned versus heterodox religious practices that continue to structure museum presentations and inform public perception of Islamic culture. By exploring the difficulties, achievements, and shortcomings of the project, and by incorporating insights from audience evaluations and impact questionnaires, this article reflects on the range of factors that shape today's presentations of Islamic art and culture in the museum, as well as on the unprecedented challenges faced by specialists of Islam in western institutions at this critical historical moment. Furthermore, by considering the exhibition in the context of the current, revitalized museological interest in religions, it offers a contribution to the broader debate about religious objects in secular institutions and the need to reconcile multiple views and expectations. 


\section{Keywords}

divination

amulets and talismans

Islam

exhibitions

museums

sensitivities

\section{Introduction: Exhibiting Belief}

The dominance of religious discourse in today's world has been recognized as the cause of a renewed interest in religious topics in the museum. ${ }^{1}$ As observed in a recent exploration of this transformative shift, 'Because religious life and practice continues to play a global role, there is a strong need for mutual understanding across, and even within, religious lines, investigations that are critical to global cooperation and progress. ${ }^{2}$ More to the point, 'religious objects have a duty to help their visitors empathize with religious people [...] [and] a unique responsibility to help visitors understand religion', which explains, in part, the proliferation of temporary exhibitions and displays centred on religious art and artefacts in the past few years. ${ }^{3}$ Some of these projects anchored their exploration of personal devotion to objects of high artistic merit. ${ }^{4}$ Others echoed the setting, behaviours, and emotive responses accompanying the actual experience of the sacred in their presentations, emphasizing its multisensory dimensions. ${ }^{5}$ In special instances, installations provided opportunities for representatives of specific faiths to determine both the exhibits and the narrative, merging personal experiences and memories with more conventional explanations. ${ }^{6}$ At the time of writing (December 2017), another blockbuster exhibition, Living with Gods: People, Places, 
and Worlds Beyond, on view at the British Museum, London, combines objects as diverse as pilgrim flasks, auspicious clothing, guardian statues, and phallus-shaped offerings to deepen the conversation about belief and explore why it matters to many people. ${ }^{7}$

Common to these initiatives is the desire to reclaim and expose the multiple facets and forms taken by religious belief and the complications raised by a public discussion on the topic, involving multiple stakeholders, specific sensitivities, institutional demands, curatorial ambitions, and public expectations. These ideas were certainly at play when, in late 2012, the Ashmolean Museum of Art and Archaeology asked me to develop an Islamic art exhibition that would be visually striking, draw crowds, not conflict with ongoing projects elsewhere in the United Kingdom, and provide an intellectual contribution to the field. ${ }^{8}$ The request initially aspired to the well-established, yet widely disputed, format of the 'treasures' show, which dominated many early public displays of Islamic art and has continued to underlie a number of post-9/11 exhibitions to this day. ${ }^{9}$ Underpinning the idea was the assumption that most of our non-academic audiences would not fully enjoy a specialized display given the relatively unfamiliar nature of the Islamic tradition, and would likelier be drawn to a surveylike installation featuring dazzling (and ideally never-before-shown) objects. ${ }^{10}$

Aside from the difficulty of offering a scholarly contribution through a mere introductory exercise, the request of museum officials exposed two important issues that had some effect on the project's subsequent development. The first was the extent to which originality and scholarship would be sacrificed in order to meet more practical objectives such as visitor numbers, media coverage, and audience appreciation, which are increasingly prevalent as key targets and measures of success in the museum world. ${ }^{11}$ The second was a failure to consider the contribution of museology and exhibitions to art historical canons and a consequent disregard for the role that our museum could play in the academic life of the university and the field of Islamic art history at large. Since reopening its doors with a $£ 61$ 
million expansion by Rick Mather Associates, the Ashmolean Museum - home to the thirdlargest Islamic collection in the United Kingdom - had not been able to offer a temporary exhibition of Islamic art due to a gap in curatorial expertise. Furthermore, the last installation involving Islamic material, Pilgrimage: The Sacred Journey - an outcome of the Ashmolean Inter-Faith Exhibition Service established in 2003 by the former Keeper of Eastern Art and Islamic art specialist James Allan - had explored the visual and material evidence of a pivotal aspect of Islam (and its cognate forms) in a comparative perspective. Islam was thus part of a grander narrative committed to examining 'subjects common to the great religions of the world', as stated in the exhibition brief. The comforting lens of the commonalities existing among the Abrahamic faiths rendered the pilgrimage project an effective contribution to the notion of Islamic art as 'a mediator for cultures in confrontation', ${ }^{12}$ an idea that continues to represent a major driving force behind cultural initiatives designed to shift public opinion about Islam. ${ }^{13}$

Yet despite the valuable educational opportunities provided by similar temporary and permanent displays of Islamic art, the excessive didactic burden put on this artistic tradition to depict related societies in a positive light and alleviate misconceptions has, in fact, served to reinforce ahistorical paradigms, severing both the artistic legacy and associated cultural realities from the geopolitical dynamics and intellectual forces that shaped and reshaped them. ${ }^{14}$ In particular, as argued by Barry Flood, the ways in which Islamic art objects have been made into tools for 'super-regional ideological projects' has turned them into repositories of 'a "true" notion of Islamic faith and culture', raising, in turn, public expectations about their ability to reflect the spirit of their makers. ${ }^{15}$ Valorizing a static past has had many side effects, most recently that of feeding into the rhetoric of a lost 'golden age of Islam' upheld by fundamentalisms and neo-imperialist propaganda alike. Such an approach has therefore only reinforced a monolithic view of this tradition, threatening its diversity. ${ }^{16}$ 
An exhibition with a generic and sweeping perspective like the 'treasures' format similarly risked having limited educational and social impact, appearing particularly ill-suited to an institution expected to contribute critically to the debate.

\section{$<$ Figure $1>$}

It was with these considerations in mind that the idea of an exhibition devoted to Islamic occultism matured [Figure 1]. As an academic museum, the Ashmolean represented the ideal place for an intellectual provocation that few other institutions could have afforded and that created an opportunity to problematize and broaden the parameters of Islamic art and culture while offering a more perceptive counternarrative to the image of Islam informed by current events and media reports. Inspired, more specifically, by the objects available in Oxford collections and a personal interest in an understudied and underrated subject, I chose to consider some of the best-documented divinatory practices and associated talismanic technologies with a view to complicating notions of belief and exposing facets of Islam that, while less well known to our diverse audiences, would still resonate with them. ${ }^{17}$ Uncovering some of Islam's 'folkloric' or 'popular' sides, as these practices tend to be categorized, but also emphasizing the universal drive underpinning them, had the potential to make the tradition more familiar to our visitors. Audience evaluations later confirmed the success of this approach. ${ }^{18}$

The proposal did not receive immediate consensus within the institution, so a number of meetings were held inside and outside the museum in order to assess its suitability. The opportunity soon arose to transform the project into a larger research effort, which benefited from the support of the Leverhulme Trust, in order to undertake a more critical assessment of the topic and make the objects part of a multidisciplinary conversation. A range of 
sensitivities associated with the subject had to be considered. One of the biggest perceived risks was that of portraying Islam as superstitious, feeding accusations of fanaticism from secular audiences on the one hand, and offending Muslim communities by seemingly belittling and misrepresenting their religion on the other. In addition, the subject's scholarly merit - or supposed lack thereof - was viewed as a threat to the institution's reputation. While the study of western occultism has achieved scholarly recognition in recent times, with a proliferation of studies, tools, and resources enhancing its credibility, ${ }^{19}$ its Islamic counterpart is still deemed unserious and inconsequential, despite recent efforts to reverse the trend, including landmark exhibitions. ${ }^{20}$

As recently noted by Matthew Melvin-Koushki, 'most Islamicists continue to reflectively regard the ubiquity of occultism in pre-modern and modern Islamicate societies either as a detritus of an immature philhellenism or, in later periods, as proof of cultural decadence and degeneracy. ${ }^{21}$ This tendency is, in part, the legacy of a post-Enlightenment view of divinatory and magic arts as primitive practices and as the early stages of a linear progress of civilizations towards religion first and science after. ${ }^{22}$ Melvin-Koushki continues,

\footnotetext{
That the Islamicate occult sciences are still considered suspect reflects a certain ensorcellment of Islamicists by the specter of Enlightenment Science. Reacting to the depredations of European colonialism [...] the well-intentioned scholarly compulsion has been to exorcize Islamicate history and culture of 'superstition' and 'magic' in an effort to banish orientalist stereotypes of cultural and scientific stagnation. ${ }^{23}$
}

The effects of this discourse may well have had some bearing on revivalist movements such as Wahhabism and Salafism, which since their inception have tried to sanitize Islam from behaviours and practices considered challenges to or deviations from Islam's original monotheism, paramount among them divination and magic. ${ }^{24}$ Curiously, then, and for 
opposite reasons, western Islamic scholarship and Islamic revivalism have converged in their effort to 'disenchant' Islam and its cultural production, rendering ongoing efforts to recover its esoteric dimensions both difficult and frowned upon.

\section{$<$ Figures 2 and $3>$}

These premises notwithstanding, plans for an exhibition on Islamic occultism progressed and the project made it into the museum's exhibition schedule. ${ }^{25}$ In the rest of this article, I am going to address how the scholarly concept and disciplinary motivation were distilled into an experience that our public could appreciate. In particular, I shall concentrate on the exhibition's title and lead image, its interpretative strategy, and, finally, its design, reflecting on the compromises made in each instance given the envisioned challenges.

\section{What's in a Title?}

When the exhibition was first proposed in January 2013, its title was 'Seeing Things Invisible: Art and the Occult in the Islamic World'. However evocative and direct, such a heading was quickly set aside for a number of reasons. First, due to its modern, mostly negative, associations, the word 'occult' was deemed off-putting, posing a major obstacle to the publicity and reception of the show. Second, the phrase 'Islamic world', which, however vaguely, tried to capture the geographic and chronological breadth of the material in the most expedient way, was also dismissed as unable to evoke the 'beautiful things' on show, as noted by a senior member of the museum. Aesthetic appreciation had to remain a primary lever of the campaign, a legitimate but admittedly reductive parameter when striving to make an unfamiliar tradition better known and understood. Yet the exhibition team was not facing a standard marketing exercise in this instance. While striving to find an appealing and thought- 
provoking formula, we needed to ensure that the title remained explicit about the theme and its cultural context in order to manage expectations and minimize criticism. ${ }^{26}$ With a topic and a tradition that are neither self-advertising nor instantly recognizable (or fully recognized), the title also had to steer away from oversimplifications and sensationalism. ${ }^{27}$

Meetings with the marketing team resulted in a number of suggestions, many of which revealed a fundamental confusion about the subject and its position vis-à-vis religion. In particular, God's agency and responsibility in sending 'signs' that men would interpret, on the one hand, and the extent to which amulets and talismans may rely on divine or saintly intercession in the Islamic tradition, on the other, challenged any attempt at classification. Complicating the matter further was the fact that some of the examined practices belong to the sphere of popular devotion, blurring the line between sacred and profane, and between what is acceptable and what is not. After various plays on the word 'divine' - e.g., 'Divine Talismans: The Supernatural in Islamic Art', 'The Divine and the Everyday', 'Divine Interventions' - and catchy, yet hazy, alliterations - e.g., 'Dragons, Dreams, and Divination', 'Prophecy and Protection: The Supernatural Power of Islamic Art' - we decided on 'Power and Protection: Islamic Art and the Supernatural' as the formula best able to capture the essence of the display. ${ }^{28}$

A final residual doubt concerned the term 'supernatural', which in the mind of colleagues in the exhibition team conjured up images of superheroes and Harry Potter's magic feats. Above all, although less ominous than 'occult', the word was still perceived as being potentially offensive, in spite of its straightforward reference to the otherworldly sphere. ${ }^{29}$ Other rounds of consultations followed, which this time involved not only fellow academics, but also focus groups and members of the different Islamic communities in Oxford. ${ }^{30}$ Interestingly, western scholars emerged as those most worried about the potentially negative connotation, possibly inclined, like many in the museum, to overthink the matter given the 
current climate, but probably also affected by a culturally ingrained suspicion of esotericism.

Our Muslim consultants, by contrast, not only considered the term unproblematic, but actually recognized it as quite relevant when talking about phenomena beyond nature and encompassing the divine. ${ }^{31}$ Their open-mindedness was also a reminder of the different relationship that Islam has traditionally had with the 'world of the unseen' ('alam al-ghayb), epitomized by the continued belief in the power of the evil eye and jinns. ${ }^{32}$ At the same time, it exposed the degree of assumption informing western perceptions of what may or may not be acceptable to others, and the challenges that this poses to communication within our increasingly diverse societies. Thus, 'supernatural' survived the trial and the title was announced to the press without further changes.

\section{$<$ Figures 4 and $5>$}

At this point, the job was only half-done. Essential for a proper reception of the project was a matching image, one that could summarize the key messages of the show and capture the title's mantra. The challenge was now with the designers, tasked with producing captivating branding whose ultimate aim was to attract audiences old and new. Of the over 120 exhibits intended for the display, only a few had the visual appeal needed for a lead image. Yet half of these had either been used for similar purposes in the past or had sectarian connotations that made them unsuitable for representing a wider context [Figure 2]. Used as an apotropaic device across Berber, Jewish, and Buddhist cultures, and recognized within various Islamic denominations, the iconic hand-shaped symbol known as the khamsa emerged as the best option [Figure 3]. ${ }^{33}$ It instantly evoked ideas of beauty and protection while capturing something of the universal drive characteristic of the methods and tools examined by the project. As our director wanted to offer a glimpse of the riches featured in the display, the 
motif was initially paired with the image of another splendid promised loan, the horoscopic chart contained in Iskandar Sultan's Nativity Book. ${ }^{34}$ The result, however, was an exceedingly busy composition, whose juxtaposition of zodiacal signs and the palm conjured up images of funfairs and cheap tarot reading stands rather than announcing a critical investigation of a broadly attested but misjudged phenomenon [Figure 4]. Perhaps more importantly, the poster's flashy appearance not only seemed oblivious to the sensitivities attached to the topic and the fact that it could not be presented light-heartedly, but also served to exaggerate the very associations with superstition and bigotry that the project was trying to problematize. ${ }^{35}$ After lengthy and animated discussions, a more muted background was chosen, producing a subtler image that did not detract from the 'star' object and managed to retain the desired texture [Figure 5]..$^{36}$

\section{'Is This Anything but Deceit and Lies?'}

How can a religion that proclaims total surrender to God also accommodate ways to know the future and influence the course of life that appear to challenge divine authority? Addressing this question was crucial for a successful interpretation strategy, an area of modern museological practice that attracts increasing attention and resources. While the objects themselves stood as the material proof of a range of attitudes within Islamic traditions towards divination, our didactical presentation of them had to make clear the rationale that connected such material evidence and at the same time develop a compelling narrative. ${ }^{37}$ Adding to the challenge was the need to achieve these aims within the unforgiving word limits imposed by the Ashmolean exhibition guidelines: 60 words for labels and up to 150 for introductory panels! Compromises had to be made.

Recognizing the prevalent biases against divination from the outset gave us the opportunity to turn a sensitive issue into an active element of the conversation. Yet a simple 
juxtaposition of positive and negative attitudes still risked portraying these practices as oversights, slips, or, worse, challenges to an otherwise clearly defined religious position about the matter. It was therefore also important to state that the Islamic tradition never had a single view about divination and to stress how debates about its permissibility mostly remained confined to theological and juridical circles. References to treatises of hisba (market regulation), which address the activities of various professional groups in the marketplace including astrologers, were used to measure the effect of these conversations on daily experience. In Ibn al-Ukhuwah's Ma'alim al-qurba fi ahkam al-hisba, for instance, we find glimpses into the form taken by astrological consultations in fourteenth-century Egypt, where they were tolerated as long as they were undertaken openly and in the main streets, and not performed behind closed doors or in alleyways. ${ }^{38}$ Underpinning Ibn al-Ukhuwah's record, however, is a social concern, not a theological one. The regulation, in fact, reflects the inconvenience generated by the close interaction of practitioners and clients, primarily women, shedding little light on the supposed question of the illicitness of certain divinatory practices. While confirming that astrologers remained active, this text provided one concrete example of how theoretical discussions impacted everyday life. At the same time, it exposed the conditions that allowed for the continued performance of such contested activities in Egypt in spite of formal objections. ${ }^{39}$

In our narrative, it was important to point out that criticisms against divination appeared also in the form of epistemological and philosophical discussions. ${ }^{40}$ The rebuke of astrology by the Hanbali jurist Ibn Qayyim al-Jawziyah (d.1350), who was one of its most vehement critics ever, is tied to empirical and methodological arguments attacking the discipline's soundness more than demonstrating its falseness. John Livingstone's examination of al-Jawziyah's principal work on the matter, the Miftah dar al-sa'adah, shows that the logic of Aristotelian physics, the constraints of human perception, and the temporary nature of 
human experience defined the limits that made astrology and its practitioners unreliable in the eyes of its critics. ${ }^{41}$ Asking rhetorically whether such divination was 'anything but deceit and lies, ${ }^{42}$ al-Jawziyah echoed some of the arguments proposed by his master Ibn Taymiyya (d.1328), who also invoked scientific reasoning to expose astrology's faults and vices. ${ }^{43}$ References to these important texts and individuals were admittedly limited in the exhibition, given its intended, non-academic audience. Nonetheless, noting the paucity of strictly theological arguments revealed the amount of work that remains to be done on relevant sources - and especially their reception and impact - in order to determine Islam's position on this thorny matter, if there ever was such a clear stance to begin with.

\section{$<$ Figures 6 and $7>$}

Focusing on the different and often competing voices from across the Islamic world had the added benefit of challenging prevalent views of Islam as a monolithic and closed entity. To this end, the debt of Islamic occultism to other traditions - from Greek and Bedouin divination, to Persian and Indian occultist knowledge - provided the basis for incorporating cross-cultural interaction into the exhibition narrative. References to Islamic cosmology and its geocentric view of the universe were made by citing their most important source, the Almagest, written in the second century by the Greek astronomer and mathematician Ptolemy and translated into Arabic under the Abbasid caliph al-Ma'mun (r.813-33) [Figure 6]. Mantic arts such as geomancy and dream interpretation were introduced through their legendary lineages and prophetic founders - Idris (Enoch) and Yusuf (Joseph) - alerting visitors to, or reminding them of, the shared prophetic tradition linking Islam to Judaism and Christianity [Figure 7]. 
Synthesis was crucial to avoid overwhelming our public. Some ideas and arguments were thus prioritized over others and then given a specific place in a hierarchy of content that was evenly distributed across the different sections of the exhibition. Such a focused approach meant that contextual and historical information was often sacrificed in order to highlight the specific contribution of individual objects to the general story, minimizing what visitors had to consume in order to retain the overarching ideas. This was possibly the toughest curatorial compromise I faced and one that, according to our evaluations, was appreciated by the audiences who prefer streamlined guidance. For the more curious and inquisitive visitors, recordings containing lengthier curatorial comments or readings and translations of key texts provided a discreet way to access further layers of information. ${ }^{44}$ The exhibition catalogue, designed as a useful textual compendium to the display, was a further source of detailed yet accessible information directed at a general readership and was equally limited in size to incentivize reading.

Last, but not least, an emphasis on personal stories and biographies was pursued, in order to offer the public revealing examples of the types of motivations and interests that prompted different Muslims to resort to divination and talismans in various times and places. ${ }^{45}$ A few impressive objects, some of which were on view for the first time, served this purpose well. The dream book of Tipu Sultan (r.1782-99), ruler of Mysore, was among the newer documents chosen to address the use of divination at the elite level. ${ }^{46}$ Unassuming in its appearance, the book reveals the high consideration given to dreams by the Indian ruler, and how he interpreted them to elucidate contemporaneous events and make decisions. ${ }^{47}$ Interestingly, the diary was discovered hidden away after the siege of Seringapatam, its secrecy reflecting not only the privacy of its author and the confidential nature of its contents, but possibly also the sensitivities surrounding the practice of dream interpretation, admitted but not universally espoused. ${ }^{48}$ Recourse to this and to other divinatory methods, which 
included bibliomancy (book divination) and astrology, reflected the intellectual resources that this increasingly isolated ruler devised for his survival, and his continuous attempt to seek divine guidance before taking action. Thus, while attesting direct use of divination, this object also reflected its user's piety, offering a tangible example of how the two intersected with and fed into each other.

\section{$<$ Figure $8>$}

Pointing at a humbler, and probably female, user was a ragged paper talisman produced in the Ottoman Empire in the late nineteenth century [Figure 8]. This was possibly one of the most fascinating items on display and is the object of a forthcoming detailed study. ${ }^{49}$ Its design, realized through stamps reproduced several times on the large surface, draws on Sufi devotion, apotropaic symbols, sacred invocations, and Qur'anic passages, as well as prayers to appease the demons held responsible for different ailments, including miscarriage. Titled $d u^{\prime} a-i$ Umm Subyan, one of these invocations occupies a prominent position on this foldable device, buttressed both visually and symbolically by the other formulas that were likely accumulated in specific sites and through the mediation of charismatic leaders. As was the case for the dream book, the stamped talisman offered another telling example of how the sacred and the profane could merge in the attempt to navigate life's challenges and resolve personal tribulations. Being a relatively modern object, it also contributed to extending the chronological span of the exhibits, which with the inclusion of a selection of cheap devotional commodities from the shrine of Eyüp in Istanbul stretched as far as 2015. ${ }^{50}$

The choice of this and additional material pushed the standard binaries found in traditional displays of Islamic art, namely higher versus lower art, elite versus popular users, centre versus periphery, mainstream versus sectarian. ${ }^{51}$ The inclusion of items produced in 
both Sunni and Shi'i milieus, in particular, helped challenge the conviction that divinatory and talismanic methods pertain to the latter only, indicating how sectarian divisions are not always adequate criteria when dealing with such complex phenomena. ${ }^{52}$ While the exhibition did not delve into this specific issue in any detail, it was nevertheless able to call people's attention to the dangers posed by generalizations and the need for contextual study to achieve more accurate understanding of both local and broader attitudes towards occult practices.

$<$ Figure $9>$

\section{Exhibition Design}

From the start, Power and Protection was conceived of as a display in three sections progressing from theory to practice. The first gallery was meant to introduce the most popular divinatory methods; followed by a room about the technologies developed to harness their insights or effects, including amulets and talismans; and a final section on the vocabulary utilized on such devices. The aim of progressing from the general to the particular was to encourage the visitors to delve into the objects as they accumulated tools that made the works more familiar and legible. Some items could arguably sit in all three sections while others might appear to be duplicates. Opportunities to reiterate unfamiliar concepts or call attention to other facets of the same type of object were, however, embraced, facilitating the absorption of information and the recognition of key motifs, be they magic squares or diagrammatic representations of prophetic relics. Some of the objects therefore were intentionally presented in multiples and across the three rooms, offering slightly different insights depending on their placement.

The tripartite organization appeared especially well suited to the Ashmolean temporary exhibition space, comprising three interconnected rooms. However, the reduced 
size of most of the items destined for the section on amulets, including personal jewellery and pocket-size Qur'ans, necessitated a more intimate presentation, which was unachievable in the second gallery due to its double-height ceiling. The decision was thus made to invert the order of the last two sections and use the final room for the display of the smaller portable devices instead. Here, panelling in a contrasting colour was added to the wall to produce a more focused backdrop, as opposed to the plain surfaces used in previous galleries. The smallest items were displayed together with their enlarged images and brief explanatory comments, inviting viewers to reflect on aspects such as specific materials and scale [Figure 9]. Because of this change, the emphasis of the new second section also had to be modified to follow more logically from the first. The intended focus on the written word was thus explored in relation to 'ilm al-huruf or lettrism (divination by letters), the fifth divinatory technique considered by the show, which in the original plan belonged to the first gallery. Unlike astrology, geomancy, oneiromancy, and bibliomancy - all explored in the first section - lettrism had the benefit of being a more explicit link with Islam due to the centrality given to the Qur'an in its performance. Joining lettrism and the Qur'an in a single space thus provided a logical context to consider the protective and curative applications of sacred words, bringing visitors closer to the holy book of Islam and a range of devotional practices that do not usually find space in standard museum presentations of this pivotal text. ${ }^{53}$ Access to readings of Qur' anic verses as ruqya (sacred incantations) via SoundCloud audio content available to visitors using smart devices - contributed to the process. For part of the audience, these recordings helped to distinguish ruqyas from standard Qur'anic recitations and did so by relying on the sense that normally communicates this difference: hearing. This, in turn, added another way to engage with the material on display, circumventing the primacy of sight. ${ }^{54}$

\section{$<$ Figure $10>$}


The Arabic alphabet proved a fruitful resource for yet another essential aspect of the installation: the galleries' look and feel. Following well-established clichés and unaware of the animated debates surrounding the exoticization of the East, ${ }^{55}$ the designer initially proposed to place dados of geometric panels on the walls of the three rooms in order to create an Islamic 'ambience'. In an effort to devise a more pertinent visual language, I invited him and the interpretation team to reflect on the unifying role that the word - inscribed, recited, or spoken - had in the story we were trying to tell. Searching for a sign that would be as evocative of Islamic aesthetics as geometry, we thus decided to experiment with Arabic and created an alphabetic design that hinted at the power that letters, when used in isolation, acquire in several Islamic occult practices. ${ }^{56} \mathrm{My}$ initial idea was to reference the muqatta' $a t-$ the fourteen letters found at the start of several Qur'anic chapters and deemed to possess special powers. ${ }^{57}$ This was reduced to a more generic reference to the Arabic alphabet, which sufficed to produce a unified and fitting look for the installation. Using a laser technique that created cut-outs loosely recalling the light-and-shadow play of mashrabiyyas (lattice screens), the redesigned panels also allowed us to evoke the ideas of secrecy and disclosure associated with occultism, finely aligning the design with the exhibition's subject [Figure 10].

\section{Conclusions}

A great deal of anxiety accompanied the genesis and the realization of Power and Protection: Islamic Art and the Supernatural, making it, possibly, one of the most challenging exhibitions mounted by the Ashmolean in its recent history. However, its success with critics and public alike confirmed the desire of museum audiences to be challenged and to be given fresh ways to engage with both familiar and unfamiliar topics, especially where lesser-known traditions are concerned. Without offering broadly appealing themes as other recent exhibitions of 
Islamic art have done ${ }^{58}$ Power and Protection nonetheless succeeded in stirring public interest in Islam, due, in part, to its emphasis on the human and universal nature of the phenomena considered. As noted by Rachel Campbell-Johnston, chief art editor of The Times, in her review, 'what begins as a scholarly investigation broadens out, breaking down the barriers erected by Islamic zealotry to embrace the hopes and fears that a wider humanity shares ${ }^{59}$ These hopes and fears proved a fertile alternative for a refreshed debate about Islam in a museum context.

\section{Acknowledgements}

The author wishes to acknowledge the Leverhulme Trust for supporting her research between 2015 and 2017 with a Research Project Grant. Versions of this article were presented at the Khalili Research Centre during the 2016-17 academic year and at the international conference From Malacca to Manchester: Curating Islamic Collections Worldwide, held in Manchester on February 23-24, 2017. Thanks are offered also to the two anonymous reviewers of this article and to the editors of this journal, foremost Ünver Rüstem, for their valuable comments, as well as to David Farrer, Dr Mallica Kumbera Landrus, and Professor Gervase Rosser for their feedback.

\section{Contributor Details}

Dr Francesca Leoni has been Curator of Islamic Art at the Ashmolean Museum of Art and Archaeology, University of Oxford, since 2011, after holding curatorial and research posts at the Museum of Fine Arts, Houston (2008-11), Rice University (2008-10), and the Metropolitan Museum of Art, New York (2007-08). Her primary area of research is Islamic illustrated and illuminated manuscripts. In addition to the forthcoming volume Islamic Occultism in Theory and Practice (co-edited with Liana Saif, Matthew Melvin-Koushki, and 
Farouk Yahya), her books include the exhibition catalogue Power and Protection: Islamic Art and the Supernatural (with Pierre Lory and Christiane Gruber, Oxford, Ashmolean Museum, 2016), Eros and Sexuality in Islamic Art (co-edited with Mika Natif, Farnham, Ashgate, 2013), and Light of the Sufis: The Mystical Arts of Islam (co-authored with Ladan Akbarnia, Houston, The Museum of Fine Arts, Houston, 2010).

\section{Endnotes}

${ }^{1}$ Crispin Paine, ed., Godly Things: Museums, Objects, and Religion (London: Leicester University Press, 2000); Peter J. Bräunlein, ed., Religion und museum: zur visuellen repräsentation von religionen im öffentischen raum (Bielefeld: Transcript, 2004); Rosemarie Beier-de-Haan and Maire-Paule Jungblut, eds, Museums and Faith (Luxembourg: Musée d'Histoire de la Ville de Luxembourg, 2010); Crispin Paine, Religious Objects in Museums: Private Lives and Public Duties (London: Bloomsbury, 2013).

${ }^{2}$ Gretchen Buggeln, Crispin Paine, and S. Brent Plate, eds, Religions in Museums: Global and Multidisciplinary Perspectives (London: Bloomsbury, 2017), 1.

${ }^{3}$ Paine, Religious Objects, 118. For the 'dismantling of the secularization theory' as the other factor impacting new presentations of religion in museums, see, more recently, Sally M.

Promey, 'Museums, Religion, and Notions of Modernity', in Buggeln, Paine, and Plate, Religions in Museums, xix-xv.

${ }^{4}$ See, for instance, The Art of Devotion in the Late Middle Ages in Europe, 1300-1500 (Rijksmuseum, Amsterdam, 1994); Puja: Expressions of Hindu Devotion (Arthur M. Sackler Gallery, London; Smithsonian Institution, Washington, DC, 1996); and Treasures of Heaven: Saints, Relics, and Devotion in Medieval Europe (Cleveland Museum of Art, Cleveland; Walters Museum, Baltimore; British Museum, London, 2010-11). 
${ }^{5}$ Spectacular Miracles: Images of Supernatural Power from Northwest Italy (Ashmolean Museum, Oxford, 2005); Madonnas and Miracles: The Holy Home in Renaissance Italy (Fitzwilliam Museum, Cambridge, 2017).

${ }^{6}$ The ongoing Faith in Birmingham exhibition (opened February 2016) at the Birmingham Art Museums and Galleries uses collection objects and loans to explore six different faiths (Judaism, Christianity, Islam, Buddhism, Hinduism, and Sikhism) practised in the city. The display benefits from periodic updates and swaps that enable it to refresh both topic and focus.

${ }^{7}$ The exhibition runs until April 8, 2018.

${ }^{8}$ Adding to the growing chorus of apologias that accompany the expression 'Islamic art', its use in the present article and the exhibition has been for the sake of convenience. Implicit in the exercise underpinning the project and its associated research, however, was the conscious attempt to highlight regional, confessional, and historical variables in relation to the objects under consideration.

${ }^{9}$ A critical review of early exhibition practices is included in the special issue of Ars Orientalis, 'Exhibiting the Middle East: Collections and Perceptions of Islamic Art', published in 2000 and, more recently, Benoît Junod, George Khalil, Stefan Weber, and Gerhard Wolf, eds, Islamic Art and the Museum: Approaches to Art and Archaeology of the Muslim World in the Twenty-First Century (London: Saqi, 2012). Exhibition projects such as Palace and Mosque: Islamic Art from the V\&A (2004) and Cosmophilia: Islamic Art from the David Collection, Copenhagen (2006) are discussed by David Roxburgh, 'After Munich: Reflections on Recent Exhibitions', in After One Hundred Years: The 1910 Exhibition 'Meisterwerke muhammedanischer Kunst' Reconsidered, eds Andrea Lermer and Avinoam Shalem (Leiden and Boston: Brill, 2010), 359-86, esp. 369-84. For more recent installations with comparable approaches, see Beauty and Belief: Crossing Bridges with the Arts of Islamic 
Cultures, organized in 2011 by Brigham Young University Museum of Art, Provo, Utah, as a way to build cultural understanding; or the 2015 Spirit and Matter: Masterpieces from the Keir Collection of Islamic Art, which inaugurated the long-term loan of this prestigious collection to the Dallas Museum of Art.

${ }^{10}$ For considerations on the priorities of modern museum policies, see Ivan Karp, Corinnne A. Kratz, Lynn Szwaja, and Tomás Ybarra-Frausto, eds, Museum Frictions: Public Cultures/Global Transformations (Durham and London: Duke University Press, 2006); and, with specific reference to Islamic art, see Roxburgh, 'After Munich', 359-60.

${ }^{11}$ Not immune to this trend, university museums face particular challenges as they develop their exhibition programmes, caught, as they are, between their traditional function as custodians and purveyors of higher learning and the growing ambition to become 'places for everybody'.

${ }^{12}$ Alan Riding, 'An Essay: Islamic Art as Mediator for Cultures in Confrontation', New York Times, April 6, 2004, accessed May 3, 2017, http://www.nytimes.com/2004/04/06/arts/anessay-islamic-art-as-a-mediator-for-cultures-in-confrontation.html. For an analysis of this issue, see Finbarr Barry Flood, 'From the Prophet to Postmodernism? New World Orders and the End of Islamic Art', in Making Art History: A Changing Discipline and Its Institutions, ed. Elizabeth Mansfield (London: Routledge, 2007), 31-53, esp. 38-43; and David Roxburgh, 'Foreign Exchange: Gift of the Sultan: The Arts of Giving at the Islamic Courts', Artforum 49.9 (2011): 145-46.

${ }^{13}$ SITES (Smithsonian Institution Temporary Exhibition Service), for instance, is currently developing an exhibition concept in collaboration with the National Library of Medicine, which aims to explore the enduring impact of Islamic medicine on current practices and modern health. 
${ }^{14}$ Wendy M. K. Shaw, 'The Islam in Islamic Art History: Secularism and Public Discourse', Journal of Art Historiography 6 (2012): 19.

${ }^{15}$ Flood, 'From the Prophet to Postmodernism?', 42.

${ }^{16}$ Ibid., 39-40. The aspiration to reinstate the unadulterated purity of such a golden past underpins Salafi and Wahhabi doctrines and the movements inspired by them, from the Taliban to the Islamic State. Jacqueline Dutton, 'Non-Western Utopian Traditions', in The Cambridge Companion to Utopian Literature, ed. Gregory Claeys (New York: Cambridge University Press, 2010), 238.

${ }^{17}$ These included techniques that relied on God's guidance, such as book divination, dream interpretation, and lettrism, as well as deductive methods such as the 'ilm al-raml (science of the sand) and astrology, all with strong pre-Islamic traditions. Similarly, many of the amulets and talismans relied on sacred formulas and designs. In addition to offering a captivating topic for younger generations and those in higher education, Power and Protection was primarily intended for a general adult public of art lovers and connoisseurs with no specific religious affiliation or background.

${ }^{18}$ Some viewers went so far as to say that they were able to see Islam's 'spiritual side' for the first time, a reaction that sheds light on the range of emotive responses that the topic elicited in its viewers. Special thanks go to Dr Farouk Yahya, Leverhulme Research Assistant, for processing the data of the visitor questionnaires that ran during the twelve weeks of the installation.

${ }^{19}$ Most useful among them are Monica Azzolini, The Duke and the Stars: Astrology and Politics in Renaissance Milan (Cambridge, MA: Harvard University Press, 2013); Francis Young, English Catholics and the Supernatural, 1553-1829 (Farham: Ashgate, 2013); Egil Asprem, The Problem of Disenchantment: Scientific Naturalism and Esoteric Discourse (Leiden: Brill, 2014); Glenn A. Magee, ed., The Cambridge Handbook of Western Mysticism 
and Esotericism (Cambridge: Cambridge University Press, 2014); Liana Saif, The Arabic Influences on Early Modern Occult Philosophy (Basingstoke: Palgrave, 2015); and Monica Black and Eric Kurlander, Revisiting the 'Nazi Occult': Histories, Realities, Legacies (Rochester: Camden House, 2015).

${ }^{20}$ See, among others, Abu Ma'shar al-Balkhi, On Historical Astrology: The Book of Religions and Dynasties, eds and trans. Keiji Yamamoto and Charles Burnett, 2 vols (Leiden: Brill, 2000); Emilie Savage-Smith, ed., Magic and Divination in Early Islam (Aldershot: Variorum, 2004); Constant Hamès, ed., Coran et talismans: textes et pratiques magiques en milieu musulman (Paris: Karthala, 2007); Venetia Porter, with Robert J. Hoyland and Alexander Morton, Arabic and Persian Seals and Amulets in the British Museum (London: British Museum, 2012); and Ahmad ibn 'Ali al-Buni, Talismans: le soleil des connaissances, trans. Pierre Lory and Jean-Charles Coulon (France: Orients editions, 2013). Paramount among the exhibitions are Falnama: Book of Omens, held in 2009 at the Freer and Sackler Gallery, Washington, DC, dedicated to book divination; and l'art secret: les ecritures talismaniques de l'afrique de l'ouest, the 2013 installation at the Institut du Monde Arabe, Paris, focusing on talismanic writing and practices in West Africa.

${ }^{21}$ Matthew Melvin-Koushki, 'Introduction: De-orienting the Study of Islamicate Occultism', Arabica: Journal of Arabic and Islamic Studies 64.3-4 (2017): 287, emphasis added. ${ }^{22}$ Randall Styers, Making Magic: Religion, Magic and Science in the Modern World (New York: Oxford University Press, 2004), 51-63.

${ }^{23}$ Melvin-Koushki, 'Introduction', 288. Of course, the illicitness of these practices had been debated in Islamic theological and juridical circles well before the modern era, as will be discussed later in this article. 
${ }^{24}$ Natana J. DeLong-Bas, Wahhabi Islam: From Revival and Reform to Global Jihad (Oxford and New York, 2004), 73-77; and Roman Loimeier, 'Patterns and Peculiarities of Islamic Reform in Africa', Journal of Religion in Africa 33.3 (2003): 254-55.

${ }^{25}$ For this I am especially grateful to the Ashmolean Museum's board of visitors and the director, Xa Sturgis, who recognized the opportunity and acknowledged the intellectual and educational responsibility of an institution currently offering one of the leading programmes on Islamic art. Thanks are due also to Professor Christopher Brown, former director of the Ashmolean, under whose tenure the project was first proposed and approved.

${ }^{26}$ For an interesting discussion on the challenges posed by exhibition titles, see Ann Landi, 'Title Fights: How Museums Name Their Shows', Art News, September 12, 2013, accessed June 17, 2017, http://www.artnews.com/2013/12/09/how-museums-title-shows/. Landi also refers to the Random Exhibition Title Generator, a website launched by Rebecca Uchill that randomly concocts catchy exhibition titles by drawing on recurrent museum and galleries jargon.

${ }^{27}$ Significantly, prior to the meeting to discuss the title, the head of marketing circulated a document containing the key messages identified for an exhibition about Andy Warhol planned immediately before ours. These included 'a celebration of the artist's work', 'stunning portraits of the rich and famous', 'iconic works as well as more unusual examples', and the 'firsts' that such an exhibition offered. This show is often celebrated as our second most successful installation in terms of attendance, even though its contribution to the subject - admittedly vast - was negligible.

${ }^{28}$ Two study groups, the first composed of adults and the second made up of younger users, reacted rather differently to this proposition. In particular, the adults were more easily captivated by the first part of the title, finding it punchier and more evocative. The use of 'plosives' (i.e., words beginning with consonants produced by blocking the flow of air) made 
the title easier to recall, as current research seems to suggest. The younger audience, by contrast, believed the beginning to be the vaguest and most unimaginative part of the heading. ${ }^{29}$ Interestingly, in 2005 the Ashmolean hosted an exhibition entitled Spectacular Miracles: Images of Supernatural Power from Northwest Italy. To my knowledge, however, no objection was made to the term at the time. Gervase Rosser, e-mail message to author, June $17,2017$.

${ }^{30}$ I take this opportunity to renew my thanks to Professor Emilie Savage-Smith, Professor Eugene Rogan, Professor Tariq Ramadan, and Dr Venetia Porter for their input and collegiality. I wish also to acknowledge the support and advice provided by the Oxford Muslim Students Association, particularly Imran Naved and Hazim Azghari, as well as Qaisra Khan, Nahla Nassar, Sheikh Ramzy (Imam at Oxford Brookes), Ahmad Sukkar, and Dr Shabbir Akhtar.

${ }^{31}$ In all these conversations, the word 'magic' was intentionally avoided, due to the negative connotations of its immediate Arabic equivalent, sihr (black magic). For an overview on the subject, see Toufic Fahd, 'Sihr' and 'Kihana', in Encyclopedia of Islam, 2nd ed., ed. P. Bearman et al., accessed June 15, 2017, http://referenceworks.brillonline.com/browse/encyclopaedia-of-islam-2. A more recent discussion on the challenges raised by terminology is found in Emilie Savage-Smith, 'Introduction: Magic and Divination in Early Islam', in Magic and Divination, xiii-li, esp. xiii and xvii-viii.

${ }^{32}$ Qur'anic references on the evil eye and jinns abound: see esp. Qur'an 6:100-12; 15:27; $34: 12-14 ; 37: 158 ; 51: 56 ; 68: 51-52 ; 72: 1-6$.

${ }^{33}$ For an overview of this symbol's various meanings and uses, see Fahmida Suleman, 'The Hand of Fatima: In Search of Its Origins and Significance', in People of the Prophet's House: Artistic and Ritual Expressions of Shi 'i Islam, ed. Fahmida Suleman (London: Azimuth 
Editions, in association with the Institute of Ismaili Studies in collaboration with the British Museum's Department of the Middle East, 2015), 173-86; and Francesca Leoni, Power and Protection: Islamic Art and the Supernatural (Oxford: Ashmolean Museum, 2016), 40-41. ${ }^{34}$ Wellcome Library, London, Ms. Persian 474, fols. 18b-19a.

${ }^{35}$ An element of exoticization seemed to be at play, with the glittering detail of this rich tradition understood by some members of the exhibition team as the factor likeliest to draw people's attention. Their drive towards visual accumulation disappointingly harked back to early displays of Islamic art. The same issue affected the early stages of design, as discussed in the last section of the article.

${ }^{36}$ The simpler image with a neutral background, deemed by our designer too close to the branding of other museums, was eventually kept for the catalogue's cover.

${ }^{37}$ Besides being scarce, objects presenting critiques of these practices were ultimately sacrificed due to their (exclusively) textual nature, which would have required lengthy explanations. This is admittedly one of the shortcomings of the installation, which, however, pointed to the catalogue for extended discussions of the various criticisms.

${ }^{38}$ Ibn al-Ukhuwah, Ma'alim al-qurba fi ahkam al-hisba, ed. Reuben Levy (London: Luzac, 1938), 67-68 and 182-84, quoted in Yahya J. Michot, 'Ibn Taymiyya on Astrology: Annotated Translations of Three Fatwas', Journal of Islamic Studies 11.2 (2000): 150 (reprinted in Savage-Smith, Magic and Divination, 277-340); and George Saliba, 'The Role of the Astrologer in Medieval Islamic Society', Bulletin d'etudes orientales 44 (1992): 49 (reprinted in Savage-Smith, Magic and Divination, 341-70). See also Pierre Lory, 'Divination and Religion in Islamic Medieval Culture', in Leoni, Power and Protection, 13-31.

${ }^{39}$ Ibn Ukhuwah's information can also be compared with Ibn Khaldun's discussion on astrology produced several decades later: The Muqaddimah: An Introduction to History, trans. Franz Rosenthal, 3 vols (London: Routledge and Kegal Paul LTD, 1958), 1:228-38. 
${ }^{40}$ I am grateful to Professor Eva Orthmann for first raising this point during a workshop held at the Ashmolean Museum on January 15, 2016.

${ }^{41}$ John W. Livingstone, 'Ibn Qayyim al-Jawziyyah: A Fourteenth Century Defense against Astrological Divination and Alchemical Transmutation', Journal of the American Oriental Society 91.1 (1971): 98-99; idem, 'Science and the Occult in the Thinking of Ibn Qayyim alJawziyah', Journal of the American Oriental Society 112.4 (1991): 598-610.

${ }^{42}$ Ibn Qayyim al-Jawziyah, Miftah dar al-sa'adat wa manshur wilayat al-'ilm wa al-iradah (Cairo: Maktabat al-Azhar, 1905-7), 462, quoted and translated in Livingstone, 'Ibn Qayyim al-Jawziyyah', 98.

${ }^{43}$ Michot, 'Ibn Taymiyya on Astrology', 160-62.

${ }^{44}$ SoundCloud audio content (https://soundcloud.com/ashmoleanmuseum/sets/powerandproctection) was accessible to smartphone users through the free WiFi available in the temporary galleries of the Ashmolean Museum. Likewise, a companion website (http://www.ashmolean.org/exhibitions/powerprotection/exhibition/) offered additional content that could also be experienced via portable devices.

${ }^{45}$ For a recent discussion on the benefits of a biographical approach to exhibition narratives, see Amy Landau, 'Invoking Biography in Museum Presentations of Islamic Art: Successes and Challenges', in Fostering Empathy through Museums, ed. Elif M. Gokcigdem (Lanham: Rowman \& Littlefield, 2016), 181-99.

${ }^{46}$ Other objects, more extensively studied, included the already mentioned horoscope of Iskandar Sultan (Wellcome Library, London, Ms. Persian 474) and two folios from Shah Tahmasp I's Falnama (Chester Beatty Library, Dublin, MS.395). See Leoni, Power and Protection, 18-19, cat. 11 and 26, cat. 22A-B, and the bibliography therein. For a translation of Tipu's khwabnama (dream book), see Mahmud Husain, trans., The Dreams of Tipu Sultan (Karachi: Pakistan Historical Society, 1957). 
${ }^{47}$ Kate Brittlebank, 'Accessing the Unseen Realm: The Historical and Textual Contexts of Tipu Sultan's Dream Register', Journal of the Royal Asiatic Society 21.2 (2011): 159-75.

${ }^{48}$ Ursula Sims-Williams, 'Tipu Sultan's Dream Book (IO Islamic 3563)', British Library Blog, June 11, 2015, accessed May 5, 2017, http://blogs.bl.uk/asian-and-african/2015/06/tipu$\underline{\text { sultans-dream-book-io-islamic-3563.html. }}$

${ }^{49}$ Francesca Leoni, 'Wasila/Wasita: A Stamped Talisman', in Islamic Occultism in Theory and Practice: Proceedings of the Conference Held in Oxford, 6-8 January 2017, eds Francesca Leoni, Liana Saif, Matthew Melvin-Koushki, and Farouk Yahya (Brill: Leiden, forthcoming 2019).

${ }^{50}$ For this I have to thank Dr Venetia Porter, who urged me to include modern and contemporary practice to avoid relegating the phenomenon to the past. Thanks are also due to Christiane Gruber for procuring modern charms on my behalf.

${ }^{51}$ The exhibits also included Sub-Saharan and South East Asian material: Leoni, Power and Protection, cat. 39, 101-102, 105. At some point we also tried to include contemporary examples of spiritual healing collected from British Muslim practitioners. Eventually the lender decided not to share the material because of its private and sensitive nature.

${ }^{52}$ This conviction may in part be explained by the fact that most of the critical arguments against divination and talismans were developed in Sunni juridical milieus. For a discussion on how material evidence challenges this assumed divide, see the forthcoming article by Mariam Ekhtiar and Rachel Parikh, 'Power and Piety: Islamic Talismans on the Battlefield', in Leoni et al., Islamic Occultism.

${ }^{53}$ A subsection of the second gallery presented spiritual healing and the tradition of prophetic medicine (al-tibb al-nabawi) along with the tools and formulas used for specific ailments. Installed near a large fourteenth-century Qur'anic bifolio inscribed with the last two suras, 
aptly known as al-mu'awwidhatan (the verses seeking refuge), these objects spoke of the extra-liturgical use of God's word and the importance acquired by the Prophet's way of life.

${ }^{54}$ On religions as multisensory practices and the value of transcending vision as the premier sensory experience, see Sally M. Promey, ed., Sensational Religion: Sensory Cultures in Material Practice (New Haven, CT: Yale University Press, 2014); and Constance Classen, The Museum of Senses: Experiencing Art and Collections (London: Bloomsbury, 2017). ${ }^{55}$ David Roxburgh, 'Au Bonneur des Amateurs: Collecting and Exhibiting Islamic Art, ca. 1880-1910', Ars Orientalis 30 (2000): 9-38; idem, 'After Munich'; and Nasser Rabbat, 'What's in the Name? The New "Islamic Art" Galleries at the Met', Artforum 50.8 (2012): $75-78$.

${ }^{56}$ References to geometry were kept in the polygonal columns created to isolate specific spaces: see Figures 1 and 10.

${ }^{57}$ Keith Massey, 'Mysterious Letters', in Encyclopaedia of the Qur'an, ed. J. D. McAuliffe (Leiden: Brill, 2001), 3:471-77.

${ }^{58}$ See, in particular, Hajj: A Journey to the Heart of Islam, organized by the British Museum in 2012 and seen, in London and its other venues (Doha, Leiden, Paris), by over 250,000 visitors; or the recent The Art of the Qur'an, presented in 2016 at the Freer and Sackler Gallery, Washington, DC, and attended by some 120,000 visitors.

${ }^{59}$ Rachel Campbell-Johnston, 'I've Seen the Future and It's Leafed with Gold', The Times, December 2, 2016. 